\title{
HIF1 A-dependent increase in endothelin 2 levels in granulosa cells: role of hypoxia, LH/cAMP, and reactive oxygen species
}

\author{
Ronit Yalu, Adepeju Esther Oyesiji, Iris Eisenberg ${ }^{1}$, Tal $\operatorname{Imbar}^{1}$ and Rina Meidan \\ Department of Animal Sciences, The Robert H. Smith Faculty of Agriculture, Food, and Environment, The Hebrew \\ University of Jerusalem, Herzl Street, Rehovot 76100, Israel and ${ }^{1}$ IVF Unit, Department of Obstetrics and Gynecology, \\ Hadassah Hebrew University Medical Center, Mount Scopus, Jerusalem, Israel
}

Correspondence should be addressed to R Meidan; Email: rina.meidan@mail.huji.ac.il

\begin{abstract}
Hypoxia-inducible factor 1 alpha (HIF1A) and endothelin 2 (EDN2) are transiently expressed during the same time window in the developing corpus luteum (CL). In this study, we sought to investigate the involvement of LH/cAMP, reactive oxygen species (ROS), and a hypoxia-mimetic compound $\left(\mathrm{CoCl}_{2}\right)$ on HIF1A expression and how it affected EDN2 levels, using transformed human granulosa cells (thGCs) and primary bovine granulosa cells (GCs). $\mathrm{CoCl}_{2}$ elevated HIF1A protein levels in thGCs in a dose-dependent manner. Forskolin alone had no significant effect; however, forskolin and $\mathrm{CoCl}_{2}$ together further induced $\mathrm{HIF1A}$ protein and EDN2 mRNA expression in thGCs. Similarly, in primary GCs, LH with $\mathrm{CoCl}_{2}$ synergistically augmented HIF1A protein levels, which resulted in higher expression of EDN2 and another well-known hypoxia-inducible gene, VEGF (VEGFA). Importantly, LH alone elevated HIF1A mRNA but not its protein. The successful knockdown of HIF1A in thGCs using siRNA abolished hypoxia-induced EDN2 and also the additive effect of forskolin and $\mathrm{CoCl}_{2}$. We then examined the roles of ROS in thGCs: hydrogen peroxide (20 and $\left.50 \mu \mathrm{M}\right)$ elevated HIF1A protein as well as the expression of EDN2, implying that induction of HIF1A protein levels is sufficient to stimulate the expression of EDN2 (and VEGF) in normoxia. A broad-range ROS scavenger, butylated hydroxyanisole, inhibited $\mathrm{CoCl}_{2}$-induced $\mathrm{HIF1A}$ protein with a concomitant reduction in the mRNA expression of EDN2 and VEGF in thGCs. The results obtained in this study suggest that HIF1A, induced by various stimuli, is an essential mediator of EDN2 mRNA expression. The results may also explain the rise in the levels of HIF1A-dependent genes (EDN2 and VEGF) in the developing CL.
\end{abstract}

Reproduction (2015) 149 11-20

\section{Introduction}

Endothelin 2 (EDN2) is a new player in reproductive processes implicated in ovulation and corpus luteum (CL) formation (Palanisamy et al. 2006, Klipper et al. 2010, Cacioppo et al. 2014). Prevention of EDN2 action in rodents using EDN receptor antagonists resulted in unruptured follicles that failed to develop into corpora lutea (CL; Ko et al. 2006, Palanisamy et al. 2006, Cacioppo et al. 2014). Consistent with the contention that EDN2 is essential for $\mathrm{CL}$ formation, we reported that EDN2 mRNA levels were transiently expressed immediately after ovulation, in the early, developing bovine CL. EDN2 in follicles or CL was localized mainly to the luteal steroidogenic cells or luteinized human granulosa cells (GCs; Ko et al. 2006, Klipper et al. 2010, Imbar et al. 2012). GCs collected from patients with polycystic ovary syndrome (PCOS), characterized among other symptoms, by chronic oligo-ovulation or anovulation, had significantly lower EDN2 mRNA expression when compared with normally ovulating women (Imbar et al. 2012). Thus, this study helps in further establishing the roles of EDN2 in follicular rupture, ovulation, and CL formation.

In order to define the regulation of EDN2 gene expression, we had previously reported that hypoxia and luteinizing hormone (LH) each elevated EDN2 levels in GCs (Klipper et al. 2010). In fact, hypoxia (either the mimetic compound, $\mathrm{CoCl}_{2}$, or reduced oxygen) was found to strongly induce EDN2 and VEGF expression in GCs of several species examined thus far (Na et al. 2008, Kim et al. 2009, Klipper et al. 2010). Glucose transporter type 1 (SLC2A1) is yet another known hypoxia-induced gene (Shih \& Claffey 1998). Induction of EDN2 expression by $\mathrm{LH}$ and hypoxia is physiologically relevant. Hypoxia is an important physiological cue in the developing CL (Nishimura \& Okuda 2010) and, together with LH, it orchestrates the formation of $\mathrm{CL}$ and the consequent robust angiogenic process. Hypoxia in the $\mathrm{CL}$ and also in other fast-growing 
tissues, most notably tumors, induces the expression of a broad genetic program by stabilizing the transcription factors hypoxia-inducible factor 1 alpha (HIF1A) and hypoxia-inducible factor 2 alpha (HIF2A) (Semenza 2007, Brahimi-Horn \& Pouyssegur 2009). Under normoxic conditions, HIF1A undergoes $\mathrm{O}_{2}$-dependent hydroxylation by members of the prolyl hydroxylase domain (PHD) family (for reviews, see Schofield \& Ratcliffe (2004) and Kaelin (2005)). Hydroxylation marks HIF1A for ubiquitination and proteasomal degradation (Semenza 2007). When cellular oxygen levels fall, HIF1A hydroxylation is suppressed and HIF1A rapidly accumulates. Consequently, HIF1A is translocated into the nucleus and dimerizes with the constitutively expressed HIF2A subunit. The active HIF1 complex then initiates transcription of target genes by binding to hypoxia-responsive elements located in their promoter or enhancer regions (Hewitson et al. 2007), as described for genes such as VEGF and SLC2A1 (Shih \& Claffey 1998).

HIF1A can also be hormonally regulated in an oxygen-independent manner. Insulin-like growth factor 1 , for instance, augmented the accumulation of HIF1A in normoxia in several cell types (Alam et al. 2009, Sartori-Cintra et al. 2012, Yu et al. 2012). Reactive oxygen species (ROS) is another factor implicated in HIF1A accumulation. Evidence suggests that ROS increases HIF1A by directly inhibiting PHD catalytic activity (Cash et al. 2007, Kaelin \& Ratcliffe 2008). Finally, reports have also suggested that hypoxia can act independently of the HIF1A transcription factor (Bindra et al. 2005, Arany et al. 2008, Fujisaka et al. 2013).

In this study, we wished to investigate whether: i) hypoxia-induced EDN2 is HIF1A dependent, ii) LH or other cAMP-elevating agents such as forskolin also utilize HIF1A as a tool to induce EDN2, and iii) other potential inducers of HIF1A, such as ROS, would also affect EDN2 levels in GCs. To resolve these questions, we first studied the effects of LH (or cAMP) and a hypoxia-mimetic compound separately or together on HIF1A expression (mRNA and protein) and how it affected EDN2 levels. To critically determine the involvement of HIF1A in EDN2 mRNA induction, HIF1A was knocked down with specific siRNA molecules. The involvement of ROS in these processes on HIF1 A accumulation and gene expression in GCs was studied using $\mathrm{H}_{2} \mathrm{O}_{2}$ and a broad-range ROS scavenger.

\section{Materials and methods Cell cultures}

Transformed human granulosa lutein cells (thGCs; also known as SVOG) were a generous gift from N Auersperg (University of British Columbia, BC, Canada) (Lie et al. 1996). Cells were cultured in M-199/MCDB 105 (1:1), containing 10\% FCS, $2 \mathrm{mM}$ L-glutamine, $400 \mathrm{ng} / \mathrm{ml}$ hydrocortisone, and $50 \mu \mathrm{g} / \mathrm{ml}$ gentamicin sulfate (Lie et al. 1996, Kisliouk et al. 2003, Klipper et al. 2010). Cells from passages 6-22 were used. Cells were grown to $80-90 \%$ confluence on Petri dishes, trypsinized with trypsin-EDTA solution, and plated $(0.3 \times 106$ cells/well) on sixwell plates. The following day, cells were incubated with a hypoxia-mimetic compound $\mathrm{CoCl}_{2}(25-150 \mu \mathrm{M})$ alone or in the presence of $10 \mu \mathrm{M}$ forskolin in $1 \%$ FCS for $3-24 \mathrm{~h}$ as indicated. Forskolin, as an inducer of adenylyl cyclase, was used as these cells have lost most of their response to $\mathrm{LH} / \mathrm{hCG}$ (Lie et al. 1996). For experiments examining the effects of ROS, thGCs were incubated with varying doses of $\mathrm{H}_{2} \mathrm{O}_{2}(20,50$, or $100 \mu \mathrm{M})$, given as repeated boluses every $15 \mathrm{~min}$ in a serumfree medium (Chandel \& Schumacker 2000). After 2 h, cells were collected in a sample buffer for protein analysis of HIF1A by western blot or, after $3 \mathrm{~h}$, for RNA analysis of HIF1Ainducible genes by real-time PCR, or thGCs were preincubated with a broad-range ROS scavenger, butylated hydroxyanisole $(\mathrm{BHA} ; 250 \mu \mathrm{M})$, for $1 \mathrm{~h}$ and then incubated with $\mathrm{CoCl}_{2}$ for 4 or $16 \mathrm{~h}$ (for protein isolation and RNA extraction respectively) with or without forskolin in the presence or absence of BHA.

\section{Primary bovine GC culture}

Ovaries bearing large follicles (>10 $\mathrm{mm}$ in diameter) were collected at a local slaughterhouse as described previously (Meidan et al. 1990, Aflalo \& Meidan 1993, Mamluk et al. 1998). Only follicles containing $>4$ million viable cells were included in these experiments. GCs were enzymatically dispersed using a combination of collagenase type IA (5000 units), hyaluronidase III (1440 units), and DNase I (390 units) (Meidan et al. 1990, Aflalo \& Meidan 1993, Mamluk et al. 1998), and cultured overnight in DMEM-F12 containing 3\% FCS, $2 \mathrm{mM}$ L-glutamine, and penicillin $(100 \mathrm{U} / \mathrm{ml}) /$ streptomycin $(1 \mathrm{mg} / \mathrm{ml})$ solution (Biological Industries, Kibbutz Beit Hemeek, Israel). One day after isolation, bovine GCs (bGCs) were exposed to $\mathrm{CoCl}_{2}$ and/or bLH (100 ng/ml) for various time points as indicated (for RNA extraction and protein isolation respectively) at $1 \%$ FCS. Unless otherwise stated, biochemicals were purchased from Sigma, and tissue culture material from Biological Industries.

\section{Cell transfection}

ThGCs were trypsinized and plated immediately on six-well plates and cultured for $24 \mathrm{~h}$. Then cells were transfected using Lipofectamine 2000 reagent in 1\% FCS, as described previously (Rayhman et al. 2008, Klipper et al. 2010). Cells were transfected with $50 \mathrm{nM}$ siRNA constructs targeting HIF1A or with scrambled siRNA (the negative control). The HIF1A siRNA (si-HIF1A) sequence was sense, CUGAUGACCAGCAACUUGAdTdT and antisense, UCAAGUUGCUGGUCAUCAGdTdT. Scrambled siRNA sequence-negative controls were sense, UUCUCCGAACGUGUCACGUdTdT and antisense, ACGUGACACGUUCGGAGAAdTdT.

\section{RNA isolation and real-time PCR}

Total RNA was isolated from tissue and cells using Tri-Fast reagent (Peqlab Biotechnologie $\mathrm{GmbH}$, Erlangen, Germany) 
Table 1 Lists of primers for bovine and human genes.

\begin{tabular}{|c|c|c|}
\hline & Primer sequence $\left(5^{\prime}-3^{\prime}\right)$ & Accession no. \\
\hline \multicolumn{3}{|c|}{ Bovine genes } \\
\hline$\beta$-actin & $\begin{array}{l}\text { F: CGGGCAGGTCATCACCATC } \\
\text { R: GCCATCTCGTACTCGAAGTCC }\end{array}$ & AC_000182 \\
\hline EDN2 & $\begin{array}{l}\text { F: TTGCCACCTGGACATTATCT } \\
\text { R: CCTGGCACTGTAGCACTCA }\end{array}$ & NM_175714 \\
\hline$V E G F$ & $\begin{array}{l}\text { F: CCATGAACTTTCTGCTCTCTTGG } \\
\text { R: TCCATGAACTCCACCACTTCG }\end{array}$ & NM_174216 \\
\hline HIF1A & $\begin{array}{l}\text { F: ACTCATCCATGTGACCACG } \\
\text { R: TAGTTCTCCCCCGGCTAG }\end{array}$ & NM_174339 \\
\hline$S L C 2 A 1$ & $\begin{array}{l}\text { F: CGCTTCCTGCTCATTAACCG } \\
\text { R: CCTTCTTCTCCCGCATCAT }\end{array}$ & NM_174602 \\
\hline \multicolumn{3}{|c|}{ Human genes } \\
\hline EDN2 & $\begin{array}{l}\text { F: GCCAGCGTCCTCATCTAT } \\
\text { R: GCCGTAAGGAGCTGTCTGTTC }\end{array}$ & NM_001956 \\
\hline VEGF & $\begin{array}{l}\text { F: ATCGAGACCCTGGTGGACA } \\
\text { R: CCTCGGCTTGTCACATCTGC }\end{array}$ & NM_001025366 \\
\hline HIF1A & $\begin{array}{l}\text { F: ACTCATCCATGTGACCACG } \\
\text { R: TAGTTCTCCCCCGGCTAG }\end{array}$ & NM_001530.3 \\
\hline$S L C 2 A 1$ & $\begin{array}{l}\text { F: CGCTTCCTGCTCATTAACCG } \\
\text { R: CCTTCTTCTCCCGCATCAT }\end{array}$ & NM_006516.2 \\
\hline HPSE & $\begin{array}{l}\text { F: CTGAAGGCTGGTGGAGAAGT } \\
\text { R: CTAACCAGACCTTCTTGC }\end{array}$ & NM_006665.5 \\
\hline PTGS2 & $\begin{array}{l}\text { F: CCCTTCCTCCTGTGCCTGATGA } \\
\text { R: GTGAAGTGCTGGGCAAAGAATG }\end{array}$ & NM_000963.3 \\
\hline
\end{tabular}

$F$, forward; $R$, reverse.

according to the manufacturer's instructions. Real-time PCRs were performed using the Mx3000P quantitative PCR system (Stratagene, Garden Grove, CA, USA), using Platinum SYBR Green qPCR SuperMix-UDG (Invitrogen), as described previously (Kisliouk et al. 2005, Zalman et al. 2012). ACTB was used as the reference gene. Dissociation curves after each real-time run confirmed the presence of only one product and the absence of the formation of primer dimers. The threshold cycle number $(C t)$ for each tested gene $X$ was used to quantify the relative abundance of the gene; arbitrary units were calculated as $2^{-\Delta C t}=2^{-(C t \text { target gene } X-C t \text { reference gene) }}$. The primer sequences were listed in Table 1.

\section{Western blot analyses}

Cells were washed with PBS and proteins were extracted by scraping cells in a sample buffer $(100 \mathrm{mmol} / \mathrm{l}$ Tris- $\mathrm{HCl}(\mathrm{pH}$ 6.8), 20\% (v/v) glycerol, 4\% (w/v) SDS, $0.0002 \%(\mathrm{w} / \mathrm{v})$ bromophenol blue, and $1 \%(\mathrm{v} / \mathrm{v}) \quad \beta$-mercaptoethanol). All steps were carried out on ice, and samples were kept frozen until use. The protein samples were separated by $7.5-10 \%$ SDS-PAGE under reducing conditions. Proteins were electrically transferred onto a nitrocellulose membrane. After having been blocked for $2 \mathrm{~h}$ at $4{ }^{\circ} \mathrm{C}$ in TBST $(20 \mathrm{mmol} / \mathrm{l}$ Tris, $150 \mathrm{mmol} / \mathrm{l} \mathrm{NaCl}$, and $0.1 \%$ Tween 20; pH 7.6) containing $5 \%$ low-fat milk, the membranes were incubated with the following respective primary antibodies overnight at $4{ }^{\circ} \mathrm{C}$ : rabbit anti-HIF1A ( $\mathrm{H}-206$; Santa Cruz Biotechnology, Inc., diluted 1:500) used to detect human HIF1A, monoclonal antiHIF1A (Novus Biological (Cambridge, UK), diluted 1:500), used to detect bovine HIF1A, and rabbit anti-bVEGF (kindly provided by D Schams (Germany), diluted 1:1000) and rabbit anti p44/42 total MAPK (diluted 1:50 000; used as the loading control) for $2 \mathrm{~h}$ at room temperature. Then, the membranes were washed with TBST $(4 \times 5 \mathrm{~min})$ and incubated with secondary antibodies diluted in 1\% nonfat dry milk in TBST, peroxidase-conjugated goat anti-rabbit IgG (Jackson ImmunoResearch, West Grove, PA, USA), or goat anti-mouse IgG $(\mathrm{H}+\mathrm{L})(\mathrm{KPL}$, Baltimore, MD, USA) for $1 \mathrm{~h}$ at room temperature and washed as described previously. A chemiluminescent signal was generated with EZ-ECL Chemiluminescence Detection Kit for HRP (Biological Industries), and the membranes were exposed to X-ray films. The films were scanned and analyzed using the Gel-Pro 32 Software (Media Cybernetics, Silver Spring, MD, USA).

\section{Statistical analysis}

Statistical analysis was performed by one-way ANOVA followed by the Bonferroni's multiple comparison test (GraphPad Prism Software, version 6.00, San Diego, CA, USA). Results represent the mean \pm s.E.M. for at least three separate experiments as specified. Significance was defined at a value of $P<0.05$ or lower.

\section{Results}

\section{Effects of $\mathrm{CoCl}_{2}$, forskolin, and LH on HIF1A and EDN2 expression}

The studies outlined herein have utilized $\mathrm{CoCl}_{2}$ as a hypoxia-mimetic compound. $\mathrm{CoCl}_{2}$ as well as reduced oxygen tension both augmented EDN2, VEGF, and SLC2A1 mRNA levels by GCs (Supplementary Figure, see section on supplementary data given at the end of this article). HIF1A protein was determined in cells incubated with various concentrations $(25-150 \mu \mathrm{M})$ of $\mathrm{CoCl}_{2}$ only or with forskolin (Fig. 1A). Forskolin (used to activate adenylyl cyclase) given alone did not elevate HIF1A protein levels in thGCs, but it additively augmented HIF1A levels that were stimulated by $\mathrm{CoCl}_{2}$ (1.7-fold on average compared with $\mathrm{CoCl}_{2}$ alone, $P<0.04, P<0.05$, and $P<0.05$ for 25,100 , and $150 \mu \mathrm{M} \mathrm{CoCl} \mathrm{Cl}_{2}+$ forskolin when compared with $\mathrm{CoCl}_{2}$ alone respectively; Fig. 1B). Examination of EDN2 gene expression revealed a significant additive effect $(P<0.02)$ after incubation with forskolin and $\mathrm{CoCl}_{2}$ (Fig. 1C). To examine whether $\mathrm{LH}$ produces a similar effect, we employed primary bGCs that express the functional $\mathrm{LH} / \mathrm{hCG}$ receptors. A day after isolation, bGCs were incubated with varying concentrations of $\mathrm{CoCl}_{2}$ (25-100 $\mu \mathrm{M})$ with or without LH (100 ng/ml) (Fig. 2). As with thGCs, there was a dose-dependent increase in $\mathrm{CoCl}_{2}$-induced HIF1A protein in bGCs (Fig. 2A and B). $\mathrm{LH}$ alone did not elevate the HIF1A protein above the control levels. However, there was a synergistic, dosedependent effect of $\mathrm{LH}$ with $\mathrm{CoCl}_{2}$ on HIF1A protein levels (Fig. 2A and B). For instance, in the presence of LH, HIF1A protein levels were approximately threefold higher when compared with levels induced by $100 \mu \mathrm{M}$ $\mathrm{CoCl}_{2}$ alone (Fig. 2). The data presented in Fig. 2 also indicate that $\mathrm{LH}$ and $\mathrm{CoCl}_{2}$ exert different effects on the protein (Fig. 2B) and mRNA levels (Fig. 2C) of HIF1A. 
A

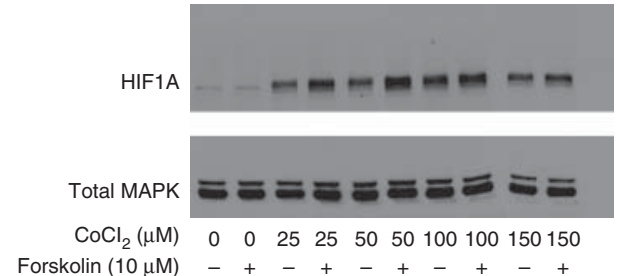

B

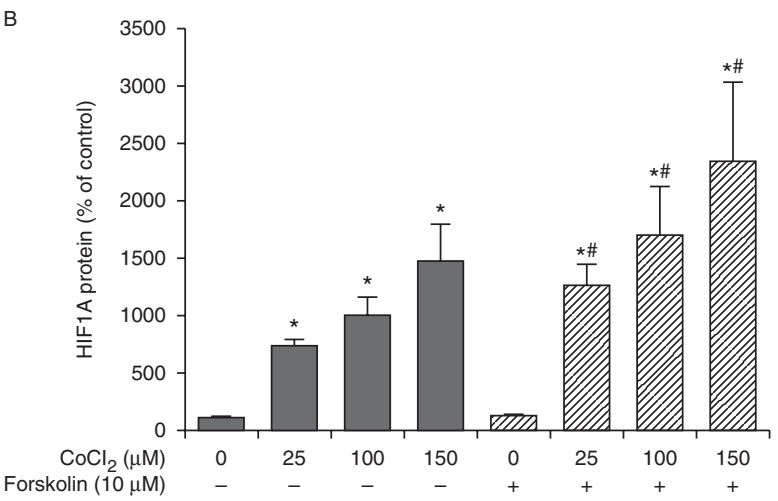

C

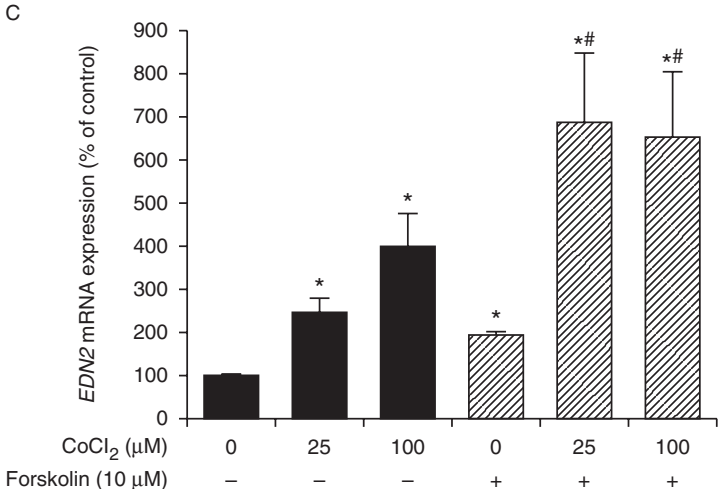

Figure $1 \mathrm{Effect}$ of $\mathrm{CoCl}_{2}$ and forskolin on HIF1A protein and EDN2 mRNA. ThGCs were cultured with varying concentrations of $\mathrm{CoCl}_{2}$ with or without forskolin $(10 \mu \mathrm{M})$ for $4 \mathrm{~h}$. (A) Representative western blots of HIF1A protein and total MAPK. (B) Quantification of HIF1A protein using GelPro 32 is depicted as the percentage change from the control (designated 100\%); the signal of anti-total MAPK (p44/42) antibody was used to correct for protein loading. (C) Cells were harvested for RNA extraction and the relative EDN2 mRNA levels were measured by real-time PCR. *Significant differences from their respective controls. "Statistically significant differences between $\mathrm{CoCl}_{2}$ alone and $\mathrm{CoCl}_{2}$ in combination with forskolin $(P<0.05$ for the protein and $P<0.02$ for $E D N 2 \mathrm{mRNA}$ ). The results (mean \pm S.E.M.) were obtained from four independent experiments.

LH only elevated the mRNA levels of HIF1A without affecting its protein concentration. $\mathrm{LH}$ and $\mathrm{CoCl}_{2}$ synergized in elevating HIF1A protein levels but not its mRNA levels (Fig. 2B and C). $\mathrm{CoCl}_{2}$ slightly, but significantly, elevated HIF1A gene expression (Fig. 2C). Importantly however, HIF1A protein levels were elevated only in the presence of $\mathrm{CoCl}_{2}$ (Fig. 2B).

To examine whether the synergistic effect of $\mathrm{LH}$ and $\mathrm{CoCl}_{2}$ on HIF1A induction was transcriptionally active, we exposed cells to these stimuli and examined gene expression. The data presented in Fig. 3 indicate that the combined effect of $\mathrm{LH}$ and $\mathrm{CoCl}_{2}$ on HIF1A induction was manifested in the profile of EDN2 and two known hypoxia-induced genes: VEGF and $S L C 2 A 1$; approximately twofold increase).

\section{Effects of HIF1A inhibition by siRNA on EDN2 expression}

To critically establish the role of HIF1A in EDN2 expression in GCs, we silenced its expression with specific siRNA. Transfection of HIF1A constructs effectively reduced HIF1A protein concentrations induced by $\mathrm{CoCl}_{2}$ approximately to $15 \%(P<0.001)$ of levels present in cells transfected with scrambled siRNA (Fig. 4A). Specificity of HIF1A silencing was demonstrated by the lack of inhibition in levels of non-hypoxia-dependent

A

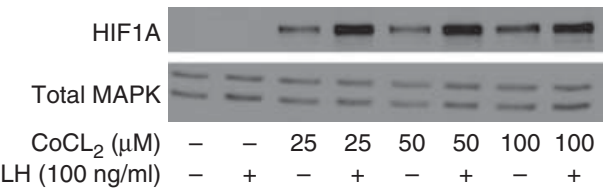

B
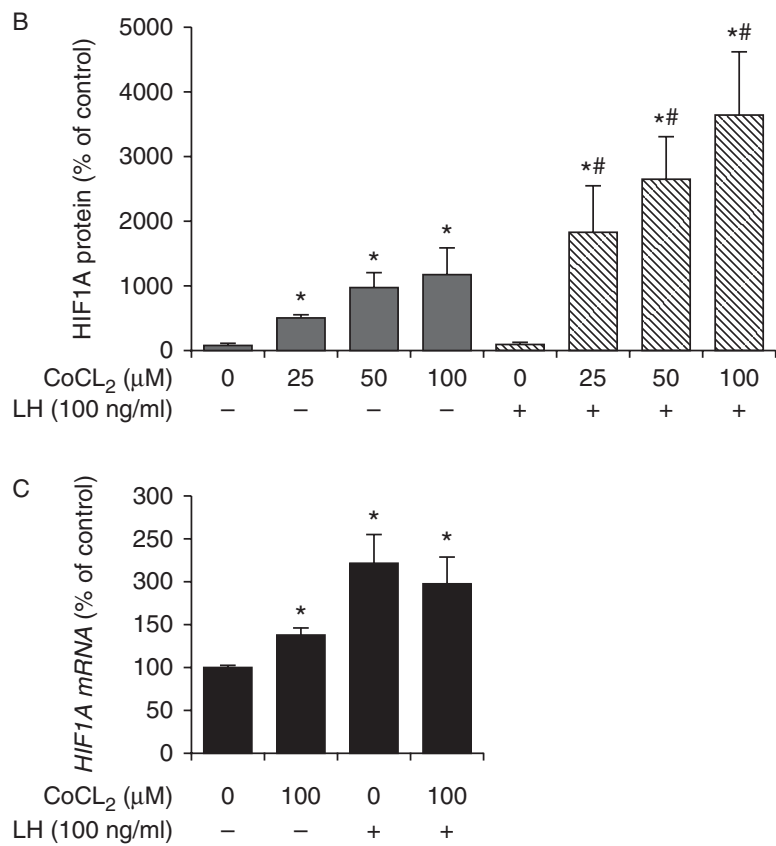

Figure 2 Effect of $\mathrm{LH}$ and $\mathrm{CoCl}_{2}$ on mRNA and protein levels of HIF1A in bGCs. Cells were incubated with varying concentrations of $\mathrm{CoCl}_{2}$ with or without $\mathrm{LH}(100 \mathrm{ng} / \mathrm{ml})$ for $4 \mathrm{~h}$. (A) Representative western blot (left panel) and quantification of HIF1A protein (right panel). (B) Quantification of HIF1A protein using GelPro 32 is depicted as the percentage change from the control (designated 100\%); the membranes were also probed with an anti-total MAPK (p44/42) antibody to correct for protein loading. (C) Relative HIF1A mRNA levels were measured by real-time PCR. *Significant differences from their respective controls. "Statistically significant differences between $\mathrm{CoCl}_{2}$ alone and $\mathrm{CoCl}_{2}$ in combination with $\mathrm{LH}(P<0.01)$. The results (mean \pm s.E.M.) were obtained from three and five independent experiments for protein and for mRNA levels respectively. 

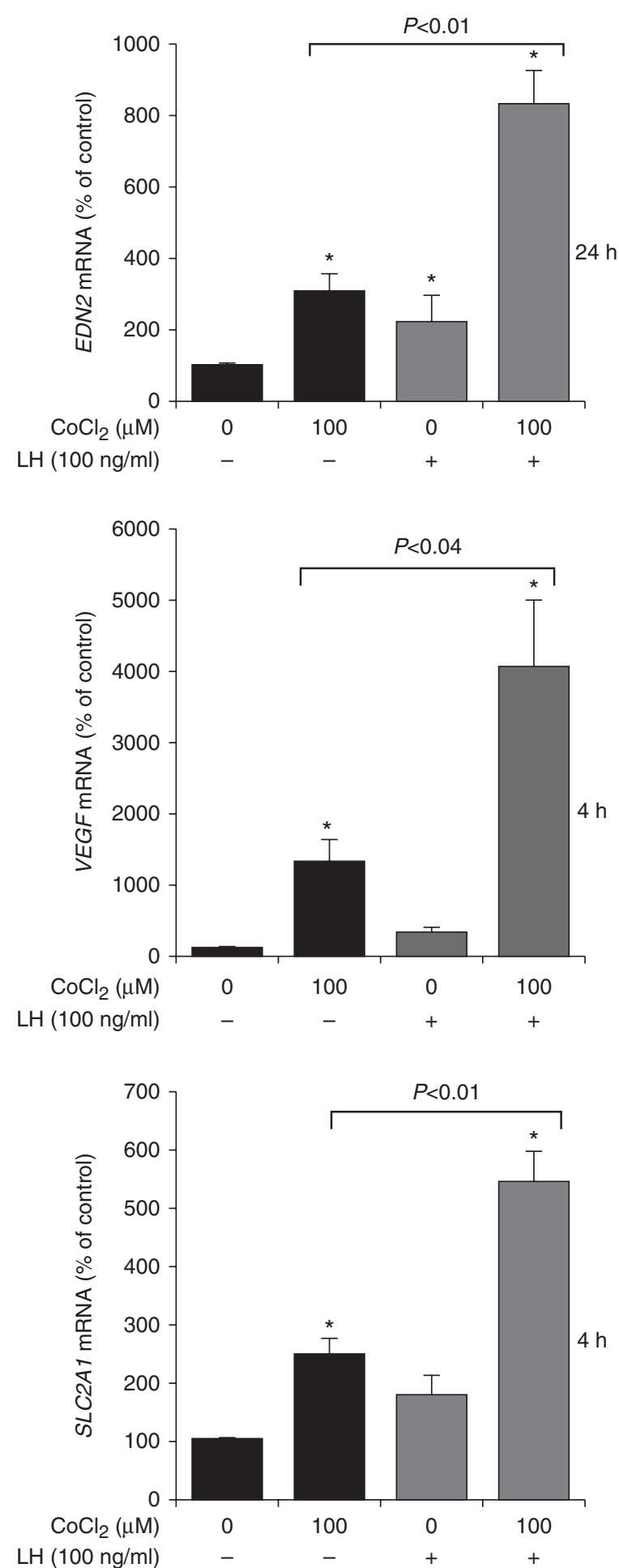

Figure $3 \mathrm{Effect}$ of $\mathrm{CoCl}_{2}$ and $\mathrm{LH}$ on the expression of hypoxia-induced genes in bGCs. Cells were cultured with $\mathrm{CoCl}_{2}(100 \mu \mathrm{M})$ with or without $\mathrm{LH}$ for 4-24 h. At the end of the incubation period, the cells were harvested for RNA extraction and EDN2,VEGF, and SLC2A1 mRNA levels were measured by real-time PCR. *Significant differences from their respective controls. The horizontal bar denotes the statistical difference between $\mathrm{CoCl}_{2}$ alone and $\mathrm{CoCl}_{2}$ in combination with $\mathrm{LH}$. The results (mean \pm s.E.M.) were obtained from four independent experiments. genes such as heparanase (HPSE) and prostaglandinendoperoxide synthase 2 (PTGS2) (Fig. 4B). To examine the effect of HIF1A silencing on gene expression, cells were transfected with either scrambled siRNA or HIF1Aspecific siRNA and, $48 \mathrm{~h}$ later, were exposed to $\mathrm{CoCl}_{2}$ for an overnight incubation. The results, presented in Fig. 5, demonstrate that HIF-silenced and $\mathrm{CoCl}_{2}$-treated cells exhibited significantly lower expression of EDN2 as well as of VEGF and SLC2A1. This was evident for both 25 and $100 \mu \mathrm{M} \mathrm{CoCl}_{2}$. HIF1A silencing also successfully reduced VEGF protein present in cells transfected with scrambled siRNA (Fig. 5). Importantly, as can be observed from Table 2, HIF1A knockdown not only reduced the effect of a hypoxia-mimetic compound but also abolished the additive effect of forskolin and $\mathrm{CoCl}_{2}$ on EDN2 mRNA levels. HIF1A silencing lowered EDN2 levels induced by forskolin alone, but this was not statistically significant (Table 2).

\section{Effects of ROS on HIF1A and EDN2 expression}

The involvement of ROS was studied using $\mathrm{H}_{2} \mathrm{O}_{2}$ and a broad-range ROS scavenger (BHA). The results presented in Fig. $6 \mathrm{~A}$ and $\mathrm{B}$ indicate that $\mathrm{H}_{2} \mathrm{O}_{2}$ augmented the levels of HIF1A protein by approximately fourfold when compared with the control. The magnitude of stimulation by 20 or $50 \mu \mathrm{M}$ was similar, suggesting that $20 \mu \mathrm{M}$ of $\mathrm{H}_{2} \mathrm{O}_{2}$ already attained the maximal stimulatory effect. $\mathrm{H}_{2} \mathrm{O}_{2}$ also significantly elevated the expression of $E D N 2$ and VEGF mRNAs (Fig. 6); actually the effect of $\mathrm{H}_{2} \mathrm{O}_{2}$ on EDN2 mRNA was higher than that of forskolin (Fig. 6). To further investigate the role of ROS, we examined the effects of BHA, ROS scavenger. The presence of BHA significantly reduced HIF1A protein levels elevated by hypoxia (2.5 times, on an average, less compared with $\mathrm{CoCl}_{2}$ alone; $P<0.05$; Fig. 7). Notably, BHA not only reduced the levels of HIF1A and the genes induced by $\mathrm{CoCl}_{2}$ but also eliminated the combined stimulatory effect of $\mathrm{CoCl}_{2}$ and forskolin on HIF1A protein and EDN2 and VEGF mRNA levels (Figs 7 and 8).

\section{Discussion}

There was a close relationship between the profiles of HIF1A protein and EDN2 expression in the various experiments utilizing primary GCs and thGCs described in this study. Stimulation of HIF1A by either the hypoxiamimetic compound alone or in combination with cAMPelevating agents (forskolin and $\mathrm{LH}$ ), or yet by $\mathrm{H}_{2} \mathrm{O}_{2}$, resulted in higher EDN2 mRNA expression (Fig. 9). Moreover, the synergistic effect of $\mathrm{LH}$ and $\mathrm{CoCl}_{2}$ on HIF1A induction was also manifested in the profile of EDN2. In accordance, inhibition of HIF1A by siRNA or by an ROS scavenger reduced EDN2 levels. Thus, the findings reported in this study imply that HIF1A is a critical mediator of EDN2 expression in GCs. The profile 
A
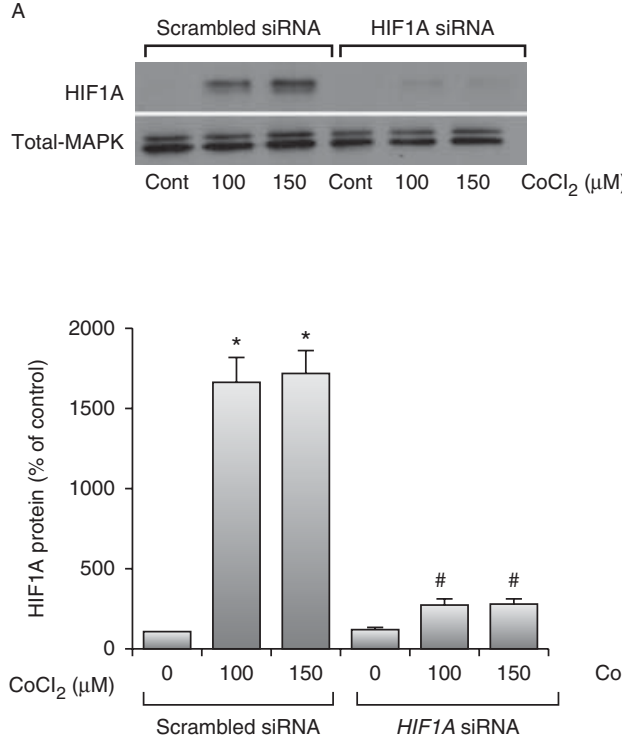
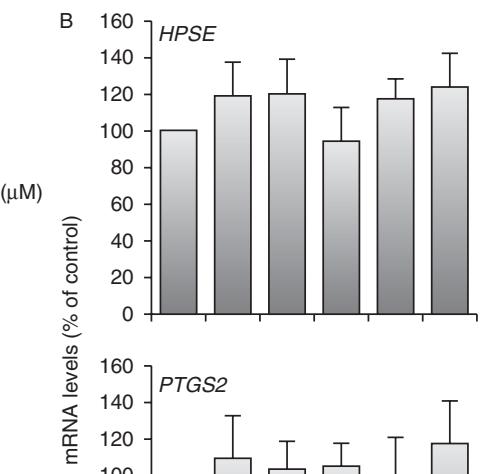

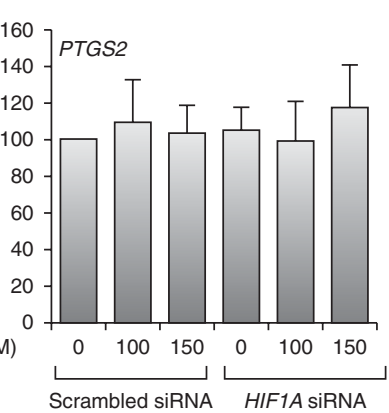

Figure 4 HIF1A silencing. ThGCs were transfected with $50 \mathrm{nM}$ of scrambled siRNA (negative control) or a HIF1A siRNA-specific sequence. Forty-eight hours after transfection, the cells were treated with 100 or $150 \mu \mathrm{M} \mathrm{CoCl}_{2}$ for $4 \mathrm{~h}$. (A, upper panel) Representative western blot of HIF1A protein in silenced vs non-silenced thGCs. (A, lower panel) Quantification of HIF1A protein levels (percentage change from the negative control designated $100 \%$ ). (B) At the end of the incubation period, the cells were harvested for RNA extraction and the mRNA levels of HPSE and PTGS2 were measured by real-time PCR. *Significant differences from their respective controls. "Statistically significant differences $(P<0.001)$ between cells treated with HIF1A and scrambled siRNA. The results (mean \pm S.E.M.) were obtained from three independent experiments. of EDN2 expression closely resembled that of VEGF and SLC2A1 - two hypoxia-induced genes that are known to be activated by HIF1A, further portraying EDN2 as a bona fide hypoxia-dependent gene.

The studies outlined herein have utilized $\mathrm{CoCl}_{2}$ as a hypoxia-mimetic agent, though, $\mathrm{CoCl}_{2}$ may not mimic all the effects of hypoxia (reduced oxygen tension); it induces HIF1A protein and also mimics many of its physiological effects (Chandel \& Schumacker 2000). Critically, Supplementary Figure demonstrates that $\mathrm{CoCl}_{2}$ and reduced oxygen tension both significantly augmented EDN2, VEGF, and SLC2A1 mRNA levels by GCs.
Hypoxic conditions exist in the newly formed $\mathrm{CL}$, because the angiogenic process lags behind the intense luteal cell proliferation. Many studies utilizing various animal species have demonstrated the accumulation, nuclear localization, and activity of HIF1 proteins following ovulation and $\mathrm{CL}$ development (Boonyaprakob et al. 2005, Duncan et al. 2008). For example, HIF1A was detected in the early luteal stage in the cow, but no expression could be found in later stages of the cycle (Nishimura \& Okuda 2010, Jiang et al. 2011). Similarly, in human CL, nuclear HIF1A protein in granulosa lutein cells was highest during luteal formation and was absent from fully functional $\mathrm{CL}$
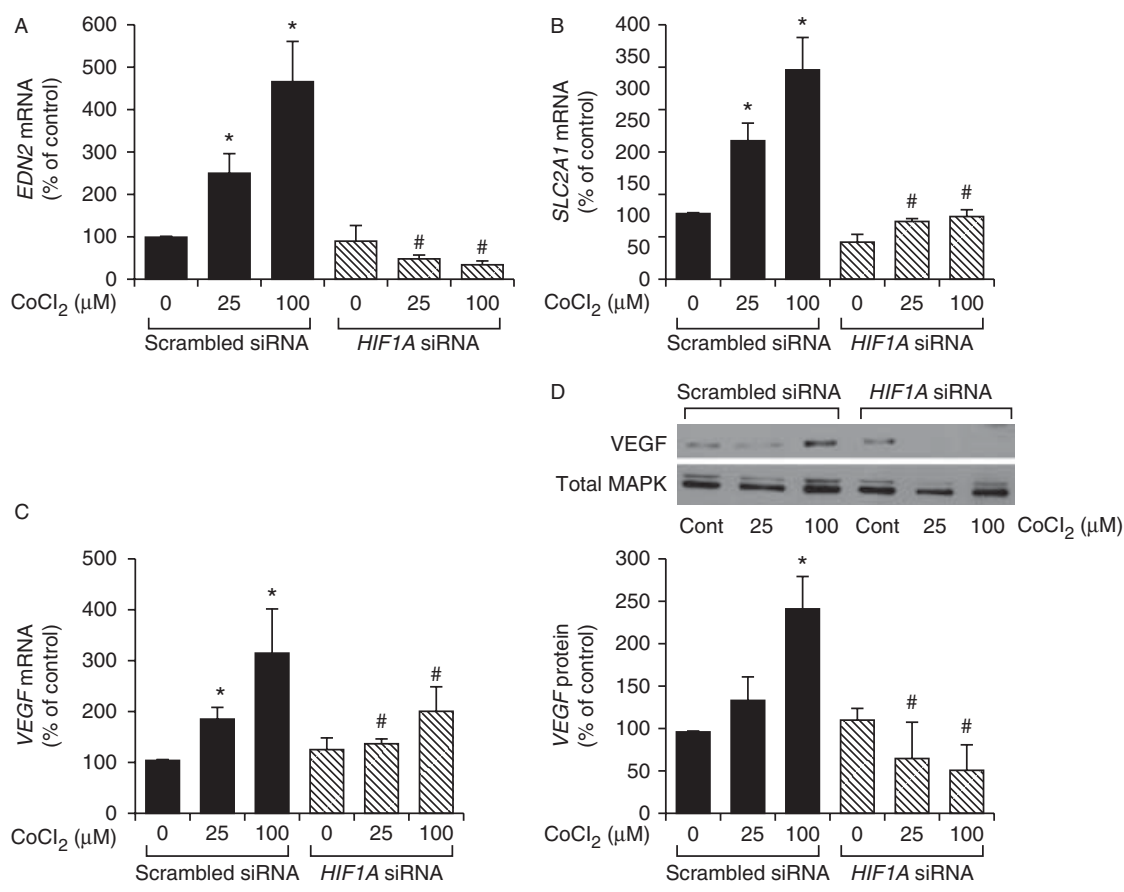

Figure 5 Effect of HIF1A silencing on EDN2, VEGF, and SLC2A1 expression. Forty-eight hours after transfection, thGCs were incubated overnight with 25 or $100 \mu \mathrm{M} \mathrm{CoCl}_{2}$. At the end of the incubation period, the cells were harvested for RNA extraction and EDN2 (A), $S L C 2 A 1(\mathrm{~B})$, and $V E G F(\mathrm{C}) \mathrm{mRNA}$ levels were measured by real-time PCR. Cells were also harvested for VEGF protein (D) determination using a specific antibody (representative blot upper panel and quantification lower panel). * Significant differences from their respective controls. ${ }^{\text {\#Statistically significant differences }}$ $(P<0.001$ for SLC2A1 and EDN2; $P<0.05$ for VEGF mRNA and protein) between cells treated with HIF1A and scrambled siRNA. The results (mean \pm s.E.M.) were obtained from three independent experiments. 
Table 2 Effect of HIF1A silencing on EDN2 mRNA levels by $\mathrm{CoCl}_{2}$ and forskolin.

\begin{tabular}{lcc}
\hline Treatment & Scrambled siRNA & HIF1A siRNA \\
\hline Control & 100 & $94 \pm 20$ \\
Forskolin $(10 \mu \mathrm{M})$ & $213 \pm 55$ & $140 \pm 32, \mathrm{NS}$ \\
$\mathrm{CoCl} 2(25 \mu \mathrm{M})$ & $268 \pm 46$ & $73 \pm 21^{*}$ \\
$\mathrm{CoCl}_{2}+$ forskolin & $475 \pm 98$ & $110 \pm 39^{*}$ \\
\hline
\end{tabular}

ThGCs were transfected with siRNA molecules as indicated in the legend to Fig. 5. EDN2 mRNA levels were determined by quantitative real-time PCR. The results (mean \pm s.E.M.) were obtained from three independent experiments. *Significant differences between scrambled and HIF1A siRNA. NS, non significant.

(van den Driesche et al. 2008). Hypoxia is therefore an important physiological cue in the developing $\mathrm{CL}$. It is well established that hypoxia plays an important role in the up-regulation of VEGF that occurs at this stage and is responsible for the angiogenic process in early $\mathrm{CL}$ (Tesone et al. 2005, van den Driesche et al. 2008, Nishimura \& Okuda 2010, Meidan et al. 2013). The current study shows that the hypoxia-mimetic compound elevated HIF1A protein and EDN2 mRNA levels, whereas HIF1A silencing (employed herein for the first time in GCs) reduced EDN2 expression and ablated its response to hypoxia. This therefore suggests that HIF1A in the developing CL may be responsible for high EDN2 mRNA levels present at this stage (Klipper et al. 2010). In addition to hypoxia, EDN2 and VEGF were induced in cells treated with forskolin or LH/hCG on their own, as demonstrated in quite a few previous studies (Klipper et al. 2010, Zhang et al. 2012, this study). This increase appears to be independent of HIF1A, because HIF1A protein was not induced by the cAMP-elevating agents and HIF1A silencing did not inhibit forskolin-induced EDN2 expression. But more than each stimuli alone, we show herein that there was a synergism between $\mathrm{LH}$ and the hypoxia-mimetic compound in inducing the levels of HIF1A and EDN2 (Fig. 9). Indeed, the highest EDN2 mRNA levels were observed in early bovine $\mathrm{CL}(\sim 30 \mathrm{~h}$ after ovulation) when both LH and hypoxia occur (Klipper et al. 2010). We show that the combined effect is the result of HIF1A being induced transcriptionally and post-transcriptionally, first enhanced transcription by $\mathrm{LH}$, which cannot be manifested in higher HIF1A protein levels unless the protein is stabilized under hypoxic conditions (Fig. 9). This issue was not clearly resolved in earlier studies that have not measured the separate and combined effects of hypoxia and cAMP in the mRNA and protein levels.

Exposure of GCs to the hypoxia-mimetic compound also enhances the levels of HIF1A and HIF2A proteins (Kim et al. 2009). Although HIF1A and HIF2A have many overlapping functions, recent studies have illustrated distinct roles for each $\alpha$-isoform in both normal physiology and disease (Keith et al. 2012). Delineation of a potential role for HIF2A in ovarian function will require further research.
PCOS is one of the most common endocrine metabolic disorders in women of reproductive age (Asuncion et al. 2000). It is characterized by anovulation, oligomenorrhea or amenorrhea, hyperandrogenism, and obesity and is related to insulin (Legro et al. 2004). Recently, we have reported that significantly lower levels of EDN2 were present in GCs derived from women with PCOS, compared with normally ovulating women (Imbar et al. 2012). Their response in culture to luteotropic agents was also different from that in the control group (Imbar et al. 2012), further demonstrating the importance of $\mathrm{LH} / \mathrm{hCG}$ in EDN2 induction. The involvement of hypoxic conditions in the abnormal responses of GCs derived from women with PCOS is yet to be investigated.

There is increasing evidence that ROS, particularly $\mathrm{H}_{2} \mathrm{O}_{2}$, also operate as signaling molecules to mediate various responses (Rhee 2006, Forman et al. 2010). It may seem paradoxical that cells respond to low $\mathrm{O}_{2}$ levels by elevating ROS formation, yet there is ample evidence that ischemia, chemical hypoxia, or low oxygen tension can induce ROS in some or most tissues (Guzy et al. 2005, Guzy \& Schumacker 2006, Walshe \& D'Amore 2008). ROS can modulate HIF1A activity by directly inhibiting the PHD catalytic activity (Chandel et al. 1998, Cash et al. 2007, Kaelin \& Ratcliffe 2008).
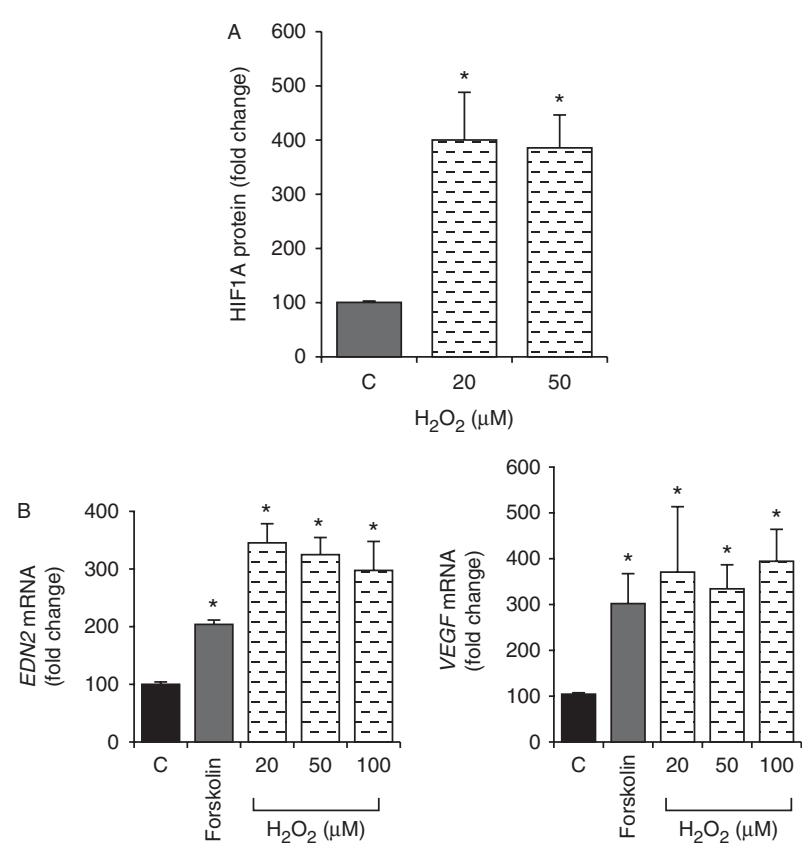

Figure 6 Effect of $\mathrm{H}_{2} \mathrm{O}_{2}$ on HIF1A protein and gene expression. (A) ThGCs were incubated with $\mathrm{H}_{2} \mathrm{O}_{2}$ for $2 \mathrm{~h}$ and harvested for protein extraction. Quantification of HIF1A protein western blot was carried out as described in the legend to Fig. 1. (B) Cells were incubated with $\mathrm{H}_{2} \mathrm{O}_{2}$ or forskolin for $3 \mathrm{~h}$, then were harvested for RNA extraction, and EDN2 and VEGF mRNA levels were measured by real-time PCR. Results are expressed as mean \pm S.E.M. for four independent experiments. *Significant differences from their respective controls. 


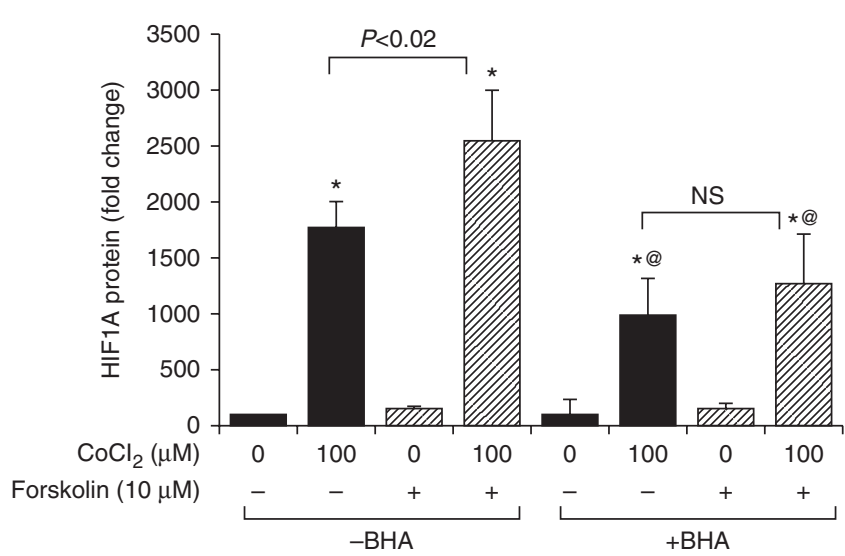

Figure 7 Effect of ROS scavengers on HIF1A protein levels. ThGCs were incubated with $\mathrm{CoCl}_{2}(100 \mu \mathrm{M})$, forskolin $(10 \mu \mathrm{M})$, or the two treatments together in the presence or absence of BHA $(250 \mu \mathrm{M})$ for $4 \mathrm{~h}$. The incubation period was preceded by preincubation for $1 \mathrm{~h}$ (with $\mathrm{BHA}$ or a control medium). Western blot and quantification of HIF1A protein were carried out as described in the legend to Fig. 1, values are relative to the control $(100 \%)$. Results are expressed as mean \pm s.E.M. for four independent experiments. *Significant differences from respective controls (without $\mathrm{CoCl}_{2}$ ). ${ }^{\circledR}$ Statistically significant differences between cells incubated with the same treatments with and without BHA.

Horizontal bar represents the statistical difference between $\mathrm{CoCl}_{2}$ alone and $\mathrm{CoCl}_{2}$ in combination with forskolin.

Substantial data link LH and ROS; for instance, LH elevated ROS levels in ovarian follicles (Yacobi et al. 2007) and hydrogen peroxide up-regulated the expression of ovulatory genes, mimicking the effect of LH (Shkolnik et al. 2011). Furthermore, LH-induced expansion of cumulus mass could be inhibited by the ROS scavenger, BHA (Shkolnik et al. 2011). However, these studies have not explored the involvement of HIF1A in ROS action. Our data are the first to provide evidence, suggesting that ROS actions in ovarian cells are mediated by HIF1A (Fig. 9). We found that $\mathrm{H}_{2} \mathrm{O}_{2}$ increased the levels of HIF1A protein in normoxic conditions. Notably, $\mathrm{H}_{2} \mathrm{O}_{2}$ significantly elevated EDN2 and VEGF mRNA levels confirming the ability of $\mathrm{H}_{2} \mathrm{O}_{2}$ to mimic $\mathrm{LH}$ actions as proposed for rat GCs (Shkolnik et al. 2011). In this study, the involvement of ROS in stabilizing HIF1A protein was also observed in cells treated with BHA. In thGCs, BHA significantly reduced the levels of HIF1A protein induced by $\mathrm{CoCl}_{2}$. The combined stimulatory effect of forskolin and $\mathrm{CoCl}_{2}$ on HIF1A protein was also significantly decreased by the presence of BHA. Notably, the expression levels of HIF1A-dependent genes (EDN2 and VEGF) were markedly reduced by $\mathrm{BHA}$, emphasizing the importance of HIF1A protein for transactivation of these genes. Our findings are in agreement with those of Chandel et al. (1998). These authors reported that Ebselen (a synthetic glutathione peroxidase mimetic that degrades $\mathrm{H}_{2} \mathrm{O}_{2}$ to $\mathrm{H}_{2} \mathrm{O}$ ) abolished mRNA expression of erythropoietin (a model protein expressed upon hypoxia), $V E G F$, and glycolytic enzymes during low oxygen tension and $\mathrm{CoCl}_{2}$ exposure (Chandel et al. 1998). The results of this study and those cited earlier indicate that ROS, most probably $\mathrm{H}_{2} \mathrm{O}_{2}$, contributes to the induction of gene expression by hypoxia (Fig. 9). These data also indicate that the mechanism underlying the synergism between LH and hypoxia may also result from the direct effects on HIF1A (mRNA and protein respectively), but may involve ROS as well. LH and hypoxia can each generate ROS production and their combined effect can result in a stronger inhibition of PHD activity, elevating consequently higher HIF1A protein levels. It should be noted that although both low oxygen levels and $\mathrm{CoCl}_{2}$ can generate ROS (most probably $\mathrm{H}_{2} \mathrm{O}_{2}$ ) (Chandel et al. 1998, Grasselli et al. 2005), $\mathrm{CoCl}_{2}$ acts via a mitochondria-independent mechanism (Chandel et al. 1998).
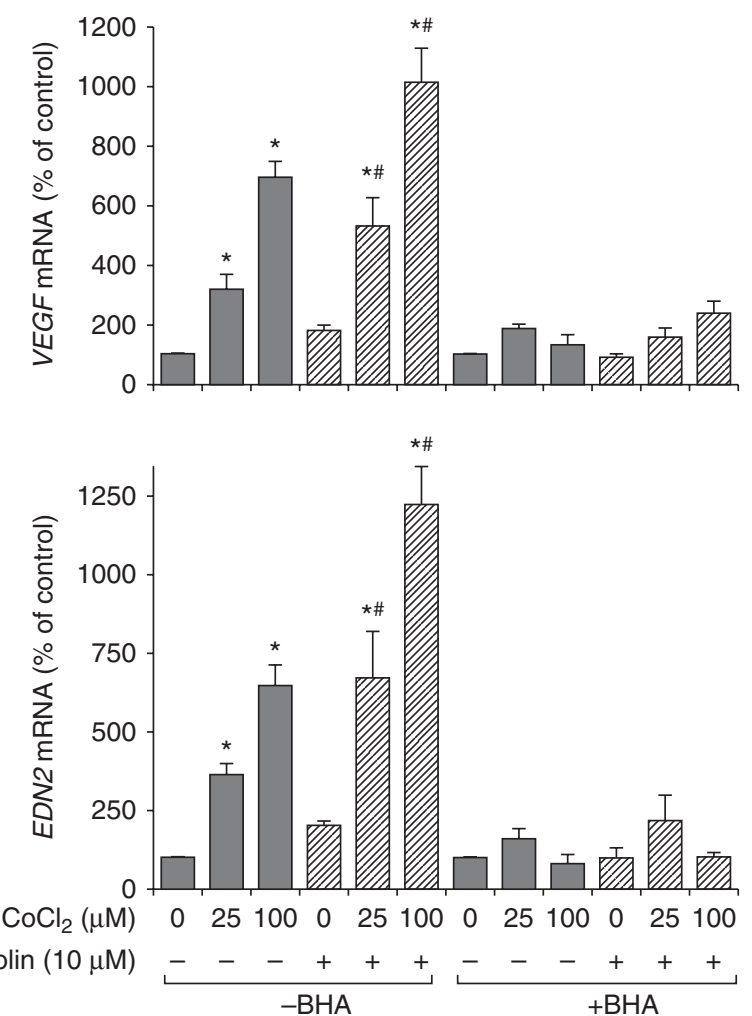

Figure 8 Effect of BHA on expression of EDN2 and VEGF. ThGCs were preincubated with BHA $(250 \mu \mathrm{M})$ for $1 \mathrm{~h}$ and then incubated with $\mathrm{CoCl}_{2}(25$ or $100 \mu \mathrm{M})$ with or without forskolin $(10 \mu \mathrm{M})$ in the presence or absence of BHA $(250 \mu \mathrm{M})$. After overnight incubation, RNA was extracted and gene expression was determined by real-time PCR. The results (mean \pm S.E.M.) were obtained from four independent experiments. *Significant differences from their respective controls (without $\left.\mathrm{CoCl}_{2}\right)$. ${ }^{\#}$ Statistically significant differences between $\mathrm{CoCl}_{2}$ alone and $\mathrm{CoCl}_{2}$ in combination with forskolin for VEGF $(P<0.06$ and $P<0.05$ for 25 and $100 \mu \mathrm{M}$ respectively), and for EDN2 $(P<0.01$ and $P<0.02$ for 25 and $100 \mu \mathrm{M}$ between $\mathrm{CoCl}_{2}$ alone and $\mathrm{CoCl}_{2}$ in combination with forskolin respectively). 


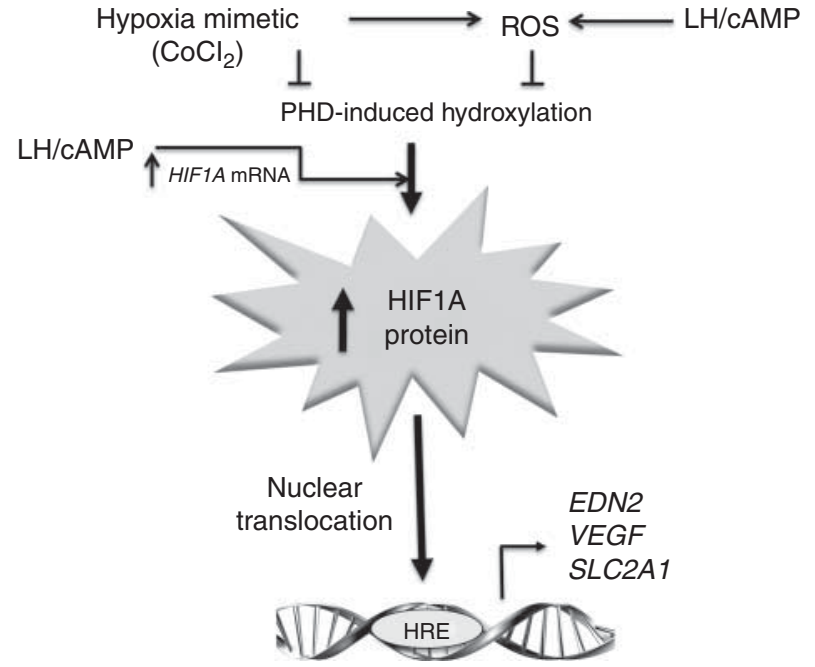

Figure 9 Schema summarizing HIF1A protein accumulation induced by a hypoxia-mimetic compound $\left(\mathrm{CoCl}_{2}\right), \mathrm{LH} / \mathrm{cAMP}$, and $\mathrm{ROS}\left(\mathrm{H}_{2} \mathrm{O}_{2}\right)$ in GCs. $\mathrm{CoCl}_{2}$ and ROS inhibit PHD-dependent hydroxylation of HIF1A, thereby stabilizing its protein levels (Chandel et al. 1998, Cash et al. 2007, Semenza 2007, Kaelin \& Ratcliffe 2008). LH and forskolin stimulate HIF1A mRNA further elevating HIF1A protein levels in the presence of a hypoxia-mimetic compound. In addition, ROS production is enhanced by $\mathrm{CoCl}_{2}$ (Chandel \& Schumacker 2000, Grasselli et al. 2005) and LH (Yacobi et al. 2007). Stabilized HIF1A protein then translocates into the nucleus, where it binds hypoxiaresponsive elements (HREs) in the $5^{\prime}$ ends of hypoxia-dependent genes such as EDN2, VEGF, and SLC2A1.

In conclusion, the data presented in this study indicate that HIF1A is an essential mediator of LH/CAMP, hypoxia, and ROS in their induction of EDN2 expression (Fig. 9). These findings are physiologically significant as they suggest a possible mechanism for optimal up-regulation of EDN2 and VEGF during ovulation and $\mathrm{CL}$ formation.

\section{Supplementary data}

This is linked to the online version of the paper at http://dx.doi. org/10.1530/REP-14-0409.

\section{Declaration of interest}

The authors declare that there is no conflict of interest that could be perceived as prejudicing the impartiality of the research reported.

\section{Funding}

This work was supported by a grant to R Meidan from the Israel Science foundation (ISF) grant number 263/10, and a grant to $\mathrm{T}$ Imbar and R Meidan from the Joint Research Fund between the Hebrew University Faculty of Medicine and Hadassah Hebrew University Medical Center.

\section{References}

Aflalo L \& Meidan R 1993 The hormonal regulation of cholesterol sidechain cleavage cytochrome P450, adrenodoxin, and their messenger ribonucleic acid expression in bovine small-like and large-like luteal cells: relationship with progesterone production. Endocrinology 132 410-416.

Alam H, Weck J, Maizels E, Park Y, Lee EJ, Ashcroft M \& HunzickerDunn M 2009 Role of the phosphatidylinositol-3-kinase and extracellular regulated kinase pathways in the induction of hypoxia-inducible factor (HIF)-1 activity and the HIF-1 target vascular endothelial growth factor in ovarian granulosa cells in response to follicle-stimulating hormone. Endocrinology 150 915-928. (doi:10.1210/en.2008-0850)

Arany Z, Foo SY, Ma Y, Ruas JL, Bommi-Reddy A, Girnun G, Cooper M, Laznik D, Chinsomboon J, Rangwala SM et al. 2008 HIF-independent regulation of VEGF and angiogenesis by the transcriptional coactivator PGC-1 $\alpha$. Nature 451 1008-1012. (doi:10.1038/nature06613)

Asuncion M, Calvo RM, San Millan JL, Sancho J, Avila S \& EscobarMorreale HF 2000 A prospective study of the prevalence of the polycystic ovary syndrome in unselected Caucasian women from Spain. Journal of Clinical Endocrinology and Metabolism 85 2434-2438.

Bindra RS, Schaffer PJ, Meng A, Woo J, Maseide K, Roth ME, Lizardi P, Hedley DW, Bristow RG \& Glazer PM 2005 Alterations in DNA repair gene expression under hypoxia: elucidating the mechanisms of hypoxiainduced genetic instability. Annals of the New York Academy of Sciences 1059 184-195. (doi:10.1196/annals.1339.049)

Boonyaprakob U, Gadsby JE, Hedgpeth V, Routh PA \& Almond GW 2005 Expression and localization of hypoxia inducible factor-1 alpha mRNA in the porcine ovary. Canadian Journal of Veterinary Research 69 215-222.

Brahimi-Horn MC \& Pouyssegur J 2009 HIF at a glance. Journal of Cell Science 122 1055-1057. (doi:10.1242/jcs.035022)

Cacioppo JA, Oh SW, Kim HY, Cho J, Lin PC, Yanagisawa M \& Ko C 2014 Loss of function of endothelin-2 leads to reduced ovulation and $\mathrm{CL}$ formation. PLoS ONE 9 e96115. (doi:10.1371/journal.pone.0096115)

Cash TP, Pan Y \& Simon MC 2007 Reactive oxygen species and cellular oxygen sensing. Free Radical Biology \& Medicine 43 1219-1225. (doi:10.1016/j.freeradbiomed.2007.07.001)

Chandel NS \& Schumacker PT 2000 Cellular oxygen sensing by mitochondria: old questions, new insight. Journal of Applied Physiology 88 1880-1889. (doi:10.1063/1.1303764)

Chandel NS, Maltepe E, Goldwasser E, Mathieu CE, Simon MC \& Schumacker PT 1998 Mitochondrial reactive oxygen species trigger hypoxia-induced transcription. PNAS 95 11715-11720. (doi:10.1073/ pnas.95.20.11715)

van den Driesche S, Myers M, Gay E, Thong KJ \& Duncan WC 2008 HCG up-regulates hypoxia inducible factor- 1 alpha in luteinized granulosa cells: implications for the hormonal regulation of vascular endothelial growth factor $\mathrm{A}$ in the human corpus luteum. Molecular Human Reproduction 14 455-464. (doi:10.1093/molehr/gan040)

Duncan WC, van den Driesche S \& Fraser HM 2008 Inhibition of vascular endothelial growth factor in the primate ovary up-regulates hypoxiainducible factor- 1 alpha in the follicle and corpus luteum. Endocrinology 149 3313-3320. (doi:10.1210/en.2007-1649)

Forman HJ, Maiorino M \& Ursini F 2010 Signaling functions of reactive oxygen species. Biochemistry 49 835-842. (doi:10.1021/bi9020378)

Fujisaka S, Usui I, Ikutani M, Aminuddin A, Takikawa A, Tsuneyama K, Mahmood A, Goda N, Nagai Y, Takatsu K et al. 2013 Adipose tissue hypoxia induces inflammatory M1 polarity of macrophages in an HIF-1 $\alpha$ dependent and HIF-1 $\alpha$-independent manner in obese mice. Diabetologia 56 1403-1412. (doi:10.1007/s00125-013-2885-1)

Grasselli F, Basini G, Bussolati S \& Bianco F 2005 Cobalt chloride, a hypoxia-mimicking agent, modulates redox status and functional parameters of cultured swine granulosa cells. Reproduction, Fertility, and Development 17 715-720. (doi:10.1071/RD05059)

Guzy RD \& Schumacker PT 2006 Oxygen sensing by mitochondria at complex III: the paradox of increased reactive oxygen species during hypoxia. Experimental Physiology 91 807-819. (doi:10.1113/expphysiol.2006.033506)

Guzy RD, Hoyos B, Robin E, Chen H, Liu L, Mansfield KD, Simon MC, Hammerling U \& Schumacker PT 2005 Mitochondrial complex III is required for hypoxia-induced ROS production and cellular oxygen sensing. Cell Metabolism 1 401-408. (doi:10.1016/j.cmet.2005.05.001) 
Hewitson KS, Schofield CJ \& Ratcliffe PJ 2007 Hypoxia-inducible factor prolyl-hydroxylase: purification and assays of PHD2. Methods in Enzymology 435 25-42.

Imbar T, Klipper E, Greenfield C, Hurwitz A, Haimov-Kochman R \& Meidan R 2012 Altered endothelin expression in granulosa-lutein cells of women with polycystic ovary syndrome. Life Sciences 91 703-709. (doi:10.1016/j.lfs.2012.06.006)

Jiang YF, Tsui KH, Wang PH, Lin CW, Wang JY, Hsu MC, Chen YC \& Chiu CH 2011 Hypoxia regulates cell proliferation and steroidogenesis through protein kinase A signaling in bovine corpus luteum. Animal Reproduction Science 129 152-161. (doi:10.1016/j.anireprosci.2011.12.004)

Kaelin WG 2005 Proline hydroxylation and gene expression. Annual Review of Biochemistry 74 115-128. (doi:10.1146/annurev.biochem.74. 082803.133142)

Kaelin WG Jr \& Ratcliffe PJ 2008 Oxygen sensing by metazoans: the central role of the HIF hydroxylase pathway. Molecular Cell 30 393-402. (doi:10.1016/j.molcel.2008.04.009)

Keith B, Johnson RS \& Simon MC 2012 HIF1 $\alpha$ and HIF $2 \alpha$ : sibling rivalry in hypoxic tumour growth and progression. Nature Reviews. Cancer 12 9-22.

Kim J, Bagchi IC \& Bagchi MK 2009 Signaling by hypoxia-inducible factors is critical for ovulation in mice. Endocrinology 150 3392-3400. (doi:10.1210/en.2008-0948)

Kisliouk T, Levy N, Hurwitz A \& Meidan R 2003 Presence and regulation of endocrine gland vascular endothelial growth factor/prokineticin-1 and its receptors in ovarian cells. Journal of Clinical Endocrinology and Metabolism 88 3700-3707. (doi:10.1210/jc.2003-030492)

Kisliouk T, Podlovni H \& Meidan R 2005 Unique expression and regulatory mechanisms of EG-VEGF/prokineticin-1 and its receptors in the corpus luteum. Annals of Anatomy 187 529-537. (doi:10.1016/j.aanat. 2005.07.005)

Klipper E, Levit A, Mastich Y, Berisha B, Schams D \& Meidan R 2010 Induction of endothelin-2 expression by luteinizing hormone and hypoxia: possible role in bovine corpus luteum formation. Endocrinology 151 1914-1922. (doi:10.1210/en.2009-0767)

Ko C, Gieske MC, Al-Alem L, Hahn Y, Su W, Gong MC, Iglarz M \& Koo Y 2006 Endothelin-2 in ovarian follicle rupture. Endocrinology 147 1770-1779. (doi:10.1210/en.2005-1228)

Legro RS, Castracane VD \& Kauffman RP 2004 Detecting insulin resistance in polycystic ovary syndrome: purposes and pitfalls. Obstetrical \& Gynecological Survey 59 141-154. (doi:10.1097/01.OGX.0000109523. 25076.E2)

Lie BL, Leung E, Leung PC \& Auersperg N 1996 Long-term growth and steroidogenic potential of human granulosa-lutein cells immortalized with SV40 large T antigen. Molecular and Cellular Endocrinology 120 169-176. (doi:10.1016/0303-7207(96)03835-X)

Mamluk R, Wolfenson D \& Meidan R 1998 LH receptor mRNA and cytochrome P450 side-chain cleavage expression in bovine theca and granulosa cells luteinized by $\mathrm{LH}$ or forskolin. Domestic Animal Endocrinology 15 103-114. (doi:10.1016/S0739-7240(97)00085-4)

Meidan R, Girsh E, Blum O \& Aberdam E 1990 In vitro differentiation of bovine theca and granulosa cells into small and large luteal-like cells: morphological and functional characteristics. Biology of Reproduction 43 913-921. (doi:10.1095/biolreprod43.6.913)

Meidan R, Klipper E, Zalman Y \& Yalu R 2013 The role of hypoxia-induced genes in ovarian angiogenesis. Reproduction, Fertility, and Development 25 343-350. (doi:10.1071/RD12139)

Na G, Bridges PJ, Koo Y \& Ko C 2008 Role of hypoxia in the regulation of periovulatory EDN2 expression in the mouse. Canadian Journal of Physiology and Pharmacology 86 310-319. (doi:10.1139/Y08-025)

Nishimura R \& Okuda K 2010 Hypoxia is important for establishing vascularization during corpus luteum formation in cattle. Journal of Reproduction and Development 56 110-116. (doi:10.1262/jrd.09-162E)
Palanisamy GS, Cheon YP, Kim J, Kannan A, Li Q, Sato M, Mantena SR, Sitruk-Ware RL, Bagchi MK \& Bagchi IC 2006 A novel pathway involving progesterone receptor, endothelin-2, and endothelin receptor B controls ovulation in mice. Molecular Endocrinology 20 2784-2795. (doi:10. 1210/me.2006-0093)

Rayhman O, Klipper E, Muller L, Davidson B, Reich R \& Meidan R 2008 Small interfering RNA molecules targeting endothelin-converting enzyme-1 inhibit endothelin-1 synthesis and the invasive phenotype of ovarian carcinoma cells. Cancer Research 68 9265-9273. (doi:10.1158/ 0008-5472.CAN-08-2093)

Rhee SG 2006 Cell signaling. $\mathrm{H}_{2} \mathrm{O}_{2}$, a necessary evil for cell signaling. Science 312 1882-1883. (doi:10.1126/science.1130481)

Sartori-Cintra AR, Mara CS, Argolo DL \& Coimbra IB 2012 Regulation of hypoxia-inducible factor-1 alpha (HIF-1 $\alpha$ ) expression by interleukin-1 beta (IL-1 $\beta$ ), insulin-like growth factors I (IGF-I) and II (IGF-II) in human osteoarthritic chondrocytes. Clinics 67 35-40. (doi:10.6061/clinics/ 2012(01)06)

Schofield CJ \& Ratcliffe PJ 2004 Oxygen sensing by HIF hydroxylases. Nature Reviews. Molecular Cell Biology 5 343-354. (doi:10.1038/ nrm1366)

Semenza GL 2007 Hypoxia-inducible factor 1 (HIF-1) pathway. Science's STKE 2007 cm8. (doi:10.1126/stke.4072007cm8)

Shih SC \& Claffey KP 1998 Hypoxia-mediated regulation of gene expression in mammalian cells. International Journal of Experimental Pathology $\mathbf{7 9}$ 347-357. (doi:10.1046/j.1365-2613.1998.00088.x)

Shkolnik K, Tadmor A, Ben-Dor S, Nevo N, Galiani D \& Dekel N 2011 Reactive oxygen species are indispensable in ovulation. PNAS $\mathbf{1 0 8}$ 1462-1467. (doi:10.1073/pnas.1017213108)

Tesone M, Stouffer RL, Borman SM, Hennebold JD \& Molskness TA 2005 Vascular endothelial growth factor (VEGF) production by the monkey corpus luteum during the menstrual cycle: isoform-selective messenger RNA expression in vivo and hypoxia-regulated protein secretion in vitro. Biology of Reproduction 73 927-934. (doi:10.1095/biolreprod.105. 039875)

Walshe TE \& D'Amore PA 2008 The role of hypoxia in vascular injury and repair. Annual Review of Pathology 3 615-643. (doi:10.1146/annurev. pathmechdis.3.121806.151501)

Yacobi K, Tsafriri A \& Gross A 2007 Luteinizing hormone-induced caspase activation in rat preovulatory follicles is coupled to mitochondrial steroidogenesis. Endocrinology 148 1717-1726. (doi:10.1210/en.20061533)

Yu J, Li J, Zhang S, Xu X, Zheng M, Jiang G \& Li F 2012 IGF-1 induces hypoxia-inducible factor 1 alpha-mediated GLUT3 expression through $\mathrm{PI} 3 \mathrm{~K} / \mathrm{Akt} / \mathrm{mTOR}$ dependent pathways in PC12 cells. Brain Research 1430 18-24. (doi:10.1016/j.brainres.2011.10.046)

Zalman Y, Klipper E, Farberov S, Mondal M, Wee G, Folger JK, Smith GW \& Meidan R 2012 Regulation of angiogenesis-related prostaglandin $\mathrm{f} 2 \alpha-$ induced genes in the bovine corpus luteum. Biology of Reproduction $\mathbf{8 6}$ 92. (doi:10.1095/biolreprod.111.095067)

Zhang J, Zhang Z, Wu Y, Chen L, Luo Q, Chen J, Huang X, Cheng Y \& Wang Z 2012 Regulatory effect of hypoxia-inducible factor-1 alpha on hCG-stimulated endothelin-2 expression in granulosa cells from the PMSG-treated rat ovary. Journal of Reproduction and Development $\mathbf{5 8}$ 678-684. (doi:10.1262/jrd.2012-089)

Received 12 August 2014

First decision 10 September 2014

Revised manuscript received 5 October 2014

Accepted 15 October 2014 